\title{
REVOLUSI INDUSTRI, LEDAKAN PENDUDUK DAN MASALAH LINGKUNGAN
}

\author{
M. Baiquni \\ Fakultas Geografi Universitas Gadjah Mada
}

\begin{abstract}
Abstrak
Peradaban manusia berubah drastis setelah terjadi perubahan paradigma ilmu pengetahuan yang diikuti dengan penemuan teknologi. Perubahan yang terjadi adalah manusia semakin berambisi menguasai dan menaklukkan alam. Melalui Revolusi Industri, ekspansi manusia semakin jelas tidak hanya meningkatnya kuantitas jumlah penduduk tetapi juga kualitas gaya kehidupan yang semakin boros dan tidak terkendali tingkat konsumsinya. Dari waktu ke waktu sumberdaya terus dieksploitasi dan polusi terus meningkat tajam, akibatnya lingkungan semakin rusak dan bencana akibat ulah manusia semakin banyak. Ironisnya kesejahteraan tidak semakin membaik, justru kesenjangan antar kelompok masyarakat semakin lebar, benturan peradaban dan peperangan semakin sering terjadi, kemaksiatan dan kerusakan moral merajalela. Lingkungan sebagai daya dukung peradaban banyak mengalami tekanan dan kerusakan terus meningkat. Bagian akhir tulisan ini melakukan refleksi hakikat manusia hadir di muka bumi sebagai pemimpin, Khalifah fil Ardh.
\end{abstract}

\begin{abstract}
Our civilization has dractically changed since new scientific revolution led to technological inventions and accelletared by industrial revolution. Human dominated to the nature. During industrial revolution the number of population has increased sharply and their lifestyle and consumption level has achieved certain level beyond that in the past. By the time natural resources is being exploited and environmental pollution and degradation is becoming worse. Ironically human welfare is not distributed equally, social gaps are wide and conflicts often happen, which are related to moral degradation. The end of this paper is a reflection on the human mandate to lead the world, Khalifah fil Ardh.
\end{abstract}

Keywords: Industrial revolution, population changes and environmental degradation.

\section{Pendahuluan}

Berbagai permasalahan lingkungan dan bencana yang akhir-akhir ini terjadi tidak lepas dari ulah manusia. Dalam dua ratus tahun terakhir perkembangan sejarah manudia terjadi sangat cepat, tidak saja dan hanya beberapa bagian dunia, tetapi perubahan kali ini telah menjadi perubahan global yang diakselerasi oleh teknologi. Umat manusia merubah posisinya dalam berinteraksi dengan alam, kini manusia lebih menguasai alam dan mengeksploitasinya untuk kemakmuran sebagian orang.

Perkembangan itu sungguh mengkhawatirkan, karena kita sudah melihat gejala kerusakan lingkungan yang nyata dan semakin sering terjadi dimana-mana. Demikian juga dengan bencana alam seperti banjir, kekeringan dan kebakaran hutan sesungguhnya akibat ulah 
manusia. Berbagai musibah yang sepertinya kerja dari alam, sesungguhnya tidak terlepas dari pengaruh manusia.

Bayangkan selama anda membaca tulisan ini, ribuan pesawat jet sedang mengudara di atmosfer dan membuang jutaan liter bahan bakar diatas atmosfir belum lagi ratusan ribu cerobong pabrik besar mengudarakan partikel debu yang dibuang ke angkasa dan jutaan kendaraan bermotor mengeluarkan asap dari kenalpot. Miliaran penduduk dunia bernafas menghidup oksigen, membuang berbagai limbah dan berulah melampaui batas-batas kebutuhan guna mencapai ambiisi keinginan yang amat melampaui batas.

Masalah teknologi tidak lepas dari ambisi manusia untuk mencapai mimpi keinginan manusia, tidak cukup dengan memenuhi kebutuhan. Penulis teringat kata-kata Mahatma Gandhi "Bumi ini cukup untuk memenuhi kebutuhan manusia, tapi tidak cukup untuk memuaskan keinginan segelintir manusia”. Antara kebutuhan yang terpenuhi dan keinginan yang terpuaskan memang mengandung filosofi yang berbeda. Inilah peradaban kita sekarang yeng menjurus pada ambisi keinginan manusia yang tidak akan pernah terpuaskan selamanya. Jadi permasalahan lingkungan hidup tidak saja pada persoalan teknologi semata, tetapi ada sesat pikir secara filosofis pula.

\section{Metode Penelitian}

Tulisan ini merupakan hasil penelitian sejumlah literatur dan data yang kemudian dirangkai dengan analisis historis dari kemajuan teknologi dan revolusi industri, perkembangan jumlah penduduk dan berbagai permasalahan lingkungan. Analisis dampak dari perilaku manusia dalam memanfaatkan sumberdaya alam juga dibahas dengan berbagai argumen dan analisis keterhubungan sebab akibat. Bagian akhir tulisan ini menggunalan penjelasan reflektif untuk menemukan hakekat tugas manusia di muka bumi.

\section{Perubahan Ilmu Pengetahuan dan Revolusi Industri}

Peradaban umat manusia mengalami perubahan yang dahsyat dalam sejarah mutakhir. Dimulai di Eropa dengan Renaissance pada abad XIV yang diawali dengan gerakan kebudayaan mencakup berbagai kesenian yang hidup di masyarakat sebagai penggerak dinamika perkembangan zaman. Berbagai pandangan baru dan penemuan-penemuan empiris ilmu pengetahuan membongkar berbagai kemapanan tradisi. Berbagai penemuan yang mendasari peradaban baru, cukup mencengangkan masyarakat pada zamannya saat itu, sehingga sempat terjadi pula berbagai ketegangan dan perseteruan faham dikalangan 
para penganut tradisi lama dan penemu baru. Berbagai penemuan baru tersebut menggerakkan masyarakat yang selama ini dibawah kungkungan kegelapan dogma, seperti memperoleh pencerahan.

Gerakan itu kemudian diikuti dengan Pencerahan atau Enlightment yang gencar dilakukan pada awal abad XVIII. Kemudian disusul dengan Revolusi Industri yang dimulai pada pertengahan abad XVIII sampai pertengahan abad XIX. Kalangan ilmuwan menjadi lebih tergerak untuk mengembangkan pemikiran dan cara pandang baru mengenai filsafat hingga fiisika dan matematika. Dengan semangat baru mereka tidak saja puas menciptakan rumus baru, tetapi muncul pembaharuan dalam melakukan uji coba dan suka menguji temuantemuan baru.

Dalam catatan sejarah, berbagai penemuan spektakuler membuat para ilmuwan berambisi selalu mengungguli yang lain. Pada 1769 James Watt dicatat sebagai pembuat mesin uap hasil penyempurnaan temuan para ilmuwan sebelumnya. Penemuan ini dianggap tonggak yang memicu revolusi industri. Berbagai mesin dikembangkan dengan basis mesin uap untuk menggerakkan kapal, kereta api dan mobil. Mesin-mesin industri juga bermunculan untuk mengolah sumberdaya alam dan bahan mentah menjadi bahan jadi secara masal yang disebut industri. Penemuan-penemuan ini merubah pola kehidupan manusia yang semula mengandalkan tenaga hewan dan manusia untuk melakukan produksi, transportasi dan kegiatan hidup lainnya, menjadi mengandalkan mesin.

Seiring dengan dikembangkan mesin-mesin tersebut, para ahli mengembangkan sumber energi mulai dari batubara hingga ditemukan minyak bumi yang diambil dari perut bumi. Energi fosil yang prosesnya memerlukan waktu jutaan tahun dan dalam kondisi tertentu itu menjadi andalan untuk kehidupan manusia modern. Kini umat manusia sangat tergantung pada sumber energi alam yang sulit diperbaharui (non-renewable) dan sampai kapan akan bertahan, tentu tidak lama lagi.

Seiring dengan penemuan dalam bidang teknik dan rekayasa yang ditandai dengan pengembangan mesin-mesin modern dan munculnya industr skala besar, berkembang pula ilmu ekonomi. Pada tahun 1776, Adam Smith mengemukakan pendapat dan berdebat tentang ekonomi pasar bebas dan melahirkan atau dianggap sebagai awal dari ilmu ekonomi. Dasar awal Ilmu Ekonomi yang lahir pada 1776 populer dengan nama pada awalnya sebagai ekonomi politik (Mubyarto, 1987). 
Berbagai penemuan ilmiah dan pengembangan teknologi dalam skala industri telah membuat perubahan besar dalam kehidupan manusia secara drastis. Dalam bidang pangan semakin meningkat jumlah produksi sebagai hasil dari perluasan lahan pertanian dan meningkatnya jumlah produksi pangan per satuan lahan. Demikian pula dengan ditemukannya teknologi pemuliaan tanaman menghasilkan bibit unggul yang dapat menghasilkan jauh lebih tinggi dibanding masa sebelumnya.

Pengembangan ilmu pengetahuan terus merasuk dalam kehidupan. Beragam jenis bibit tanaman dimodifikasi dengan teknologi yang semakin canggih. Belakangan bisnis membelokkan untuk kepentingan menguasai hasil riset yang dikembangkan dalam skala industri untuk kepentingan akumulasi keuntungan. Pangan telah menjadi bisnis besar dan bahkan memiliki kekuatan politik yang menentukan.

Dalam bidang kesehatan semakin banyak obat-obatan ditemukan dan ilmu kedokteran berkembang menghasilkan upaya peningkatan kualitas pelayanan kesehatan yang semakin baik. Jumlah kelahiran terus meningkat dan usia harapan hidup semakin panjang, menimbulkan akumulasi jumlah penduduk yang terus meningkat. Berbagai kebutuhan hidup seperti sandang dan papan terus berkembang seiring dengan permintaan akan kebutuhan tersebut, disisi lain supplai terus meningkat karena barang-barang tersebut dapat diproduksi secara masal dalam skala industri.

Perkembangan tersebut diikuti dengan berbagai perubahan besar-besaran baik dalam kerekayasaan industri maupun pemanfaatan sumberdaya alam. Belakangan istilah ekologi mulai populer digunakan oleh seorang sarjana Jerman yaitu Ernst Haeckel pada tahun 1869 (Dwidjoseputro, 1991). Orang mulai tertarik pula untuk melihat ekosistem dalam lingkup yang lebih luas (mengkaji alam semesta) dan lingkup yang kecil (meneliti kehidupan mikro-organisme).

Ekspansi manusia menguasai dunia dilakukan dengan kolonialisme terus berlangsung dari abad XVI hingga pertengahan abad XX. Bangsa Eropa tidak saja mengirimkan ekspedisi para ahli geografi mengarungi samudera menemukan benua baru, tetapi kemudian diikuti ekspansi penguasaan sumberdaya. Pada masa itu terjadi eksploitasi sumberdaya manusia melalui perbudakan dari Afrika khususnya yang dipekerjakan di benua baru Amerika. Sementara itu di Asia dan di Latin Amerika terjadi penghisapan nilai tambah sumberdaya manusia dan alam yang diangkut ke negara-negara yang kini maju dan makmur yaitu 
Eropa. Perluaan pengaruh tidak hanya melalui perdagangan, tetapi juga menduduki dan menjajah serta mengeksploitasi sumberdaya alam dengan cara perbudakan..

Ekspansi kolonial tersebut mengalami perlawanan dari dalam dari bangsa yang di jajah. Disisi luar terjadi persaingan penguasaan wilayah pengaruh diantara bangsa-bangsa penjajah hingga terjadi konflik dan memuncak sebagai Perang Dunia. Melihat pertarungan kekuatan penjajah saling menjatuhkan, timbul kesadaran berbangsa dan bernegara semakin kuat. Setelah Perang Dunia II, yang merupakan ajang adu kekuatan para penjajah berakhir, muncullah negara-negara yang menyatakan merdeka. Pada giliran selanjutnya berbagai negara membenahi puing-puing akibat perang dan memulai pembangunan.

Setelah kolonialisme berakhir melalui Perang Dunia II, era baru mulai yaitu Pembangunan sebagai suatu bentuk penataan kehidupan setelah lama dalam cengkeraman penjajahan dan konflik berkepanjangan. Istilah pembangunan mulai populer ketika Presiden Amerika waktu itu Harry S. Truman melontarkannya sebagai resep baru untuk mengatasi keterbelakangan negara-negara Selatan (bekas jajahan Eropa) maupun dalam rangka memperbaiki wilayah bekas perang di Eropa dan Asia. Saat itu Amerika berada pada posisi pemenang secara politis (adidaya) maupun secara posisi unggul peradabannya (adibudaya). Truman dalam pidato kenegaraan yang bernada propaganda mengatakan:

"We must embark on a bold new paradigm for making the benefits of our scientific advances and industrial progress available for the improvement and growth of underdeveloped areas" (Esteva, 1992).

\section{Ledakan Jumlah Penduduk}

Perkembangan peradaban ini mendorong peningkatan jumlah penduduk yang luar biasa. Perbaikan dalam bidang makanan dan gizi, peningkatan kesehatan dan lingkungan, berbagai kemudahan teknologi dan peningkatan kualitas hidup mendorong orang untuk terus berkembang, termasuk melangsungkan keturunan. Fenomena "ledakan penduduk" tidak terelakkan lagi, setelah revolusi industri hanya sekitar dua abad terakhir jumlah manusia berkembang dahsyat dari sekitar satu milyar menjadi enam milyar. Bagaimana masa depan manusia dan nasib bumi kita, bila kecenderungan jumlah penduduk terus meningkat dan konsumsi terus berkembang pula?

Al Gore secara gamblang menjelaskan dalam film Inconvinient Truth bahwa selama 10.000 generasi manusia jumlah penduduk tidak pernah melampaui 1 milyar. Kini hanya dalam satu generasi, yaitu generasi kita, angka jumlah penduduk meningkat dahsyat dari 1 
milyar menjadi 6 milyar bahkan tidak lama lagi kita akan menyaksikan jumlahnya akan mencapai 9 milyar. Sebuah perubahan yang amat drastis dan mengubah sejarah peradaban umat manusia. Ia kemudian mengkhawatirkan bahwa peradaban manusia akan bertabrakan dengan Bumi dalam tiga hal yang saling mengait.

Pertama soal jumlah penduduk yang begitu besar akan memerlukan sumberdaya dan energi yang luar biasa dari alam, belum lagi dampak polusi lingkungan yang ditimbulkan pembangunan. Kedua teknologi yang terus berkembang melampaui kemampuan kendali manusia untuk mengaturnya. Ketiga persoalan moral ketika pembangunan tidak dapat menciptakan perbaikan, tetapi justru banyak menimbulkan kerusakan lingkungan dan kehancuran daya dukung kehidupan (Al Gore, 2007).

Dalam perkembangan jumlah penduduk yang amat drastis ini dikenal dengan fenomena "Model Transisi Demografi". Pada fase pertama, penduduk pada era preindustri mengalami angka kelahiran tinggi dan diikuti angka kematian yang tinggi pula. Banyak bayi yang lahir meninggal dan resiko tinggi dialami pula ibu yang mengandung dan melahirkan. Pada masa pertumbuhan anak sering mengalami gizi buruk dan sakit sehingga usia harapan hidup relatif rendah. Pada kondisi seperti ini, jumlah penduduk tidak mengalami pertumbuhan yang tinggi sehingga jumlah penduduk pada preindustri jumlahnya tidak banyak (Gambar 1).

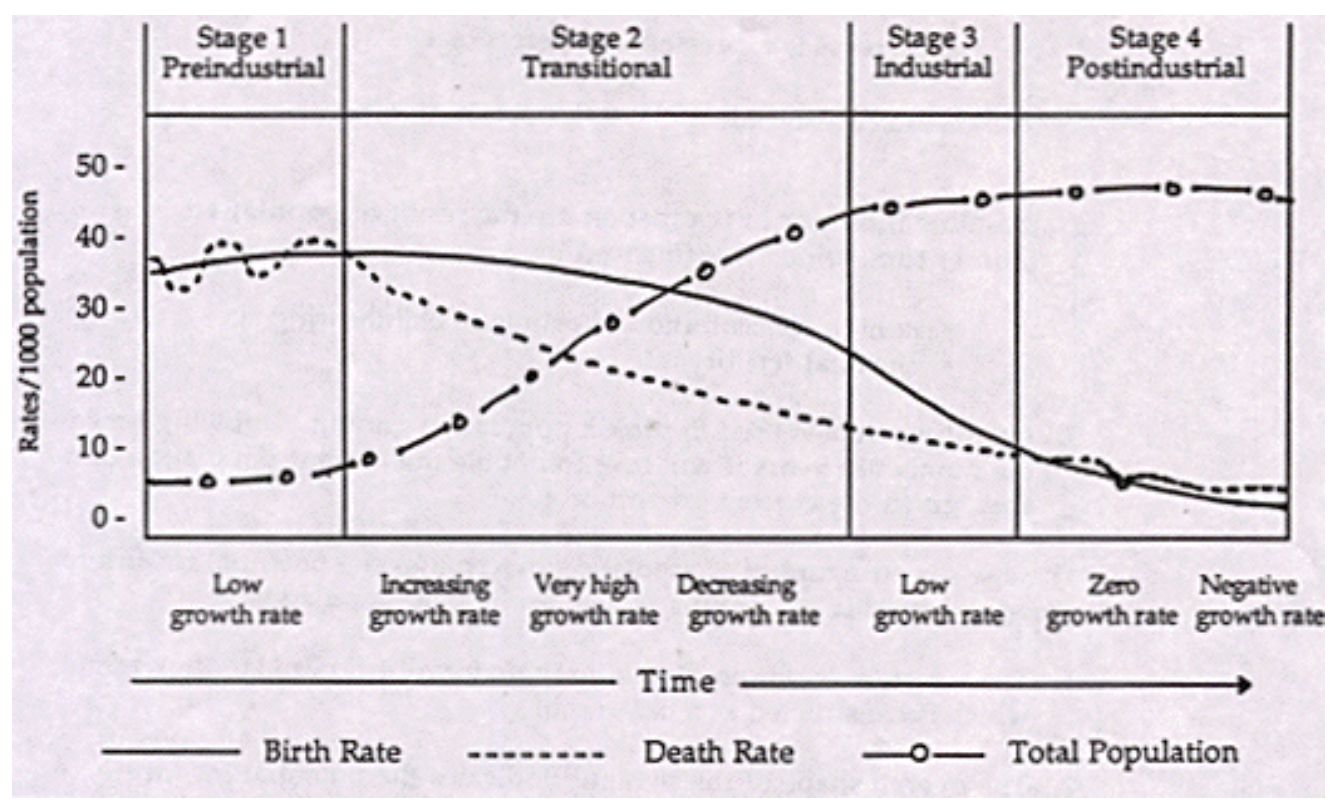

Gambar 1. Grafik Model Transisi Demografi (http://www.hawaii.edu/hga/GAW98/Michal/imageM/FIG1.GIF) 
Pada fase kedua merupakan transisi awal yang ditandai dengan masih tingginya angka kelahiran, namun terjadi penurunan angka kematian yang cukup signifikan. Pada fase ini terjadi berbagai perubahan yang ditandai dengan peningkatan gizi karena ketersediaan pangan dan perbaikan kualitas kesehatan. Dengan demikian usia harapan hidup semakin panjang sebagai hasil dari penduduk yang sehat dan tidak banyak mengalami wabah penyakit sebagaimana yang pernah terjadi pada masa sebelumnya. Fenomena kelahiran yang tinggi dan usia harapan hidup yang semakin panjang, mempengaruhi jumlah penduduk yang meningkat drastis diistilahkan sebagai "ledakan penduduk".

Fase ketiga merupakan transisi lanjut yang ditandai dengan menurunnya angka kelahiran, namun karena jumlah penduduk yang tinggi menimbulkan "ledakan penduduk" mencapai puncaknya. Masalah kependudukan dirasakan cukup berat dalam mencukupi pangan dan kebutuhan dasar kesehatan, pendidikan maupun penghidupan. Penduduk mulai menerapkan penjarangan kelahiran dengan Keluarga Berencana dikampanyekan pemerintah terutama di negara sedang berkembang. Pertumbuhan penduduk mencapai suatu puncak jumlah penduduk yang tinggi.

Fase keempat merupakan era industri dimana situasi kependudukan telah mengalami stabilitas dalam jumlah yang sudah sangat tinggi. Angka kelahiran rendah dan angka kematian rendah pula, namun karena jumlah penduduk telah mencapai angka yang tinggi menimbulkan implikasi pemenuhan kebutuhan hidup yang tinggi pula. Fenomena yang menonjol di era industri adalah adanya gaya hidup dan tingkat konsumsi yang meroket. Kebutuhan energi meningkat, sumberdaya alam dieksploitasi dan pangan dilipatgandakan untuk memenuhi ambisi segelintir penduduk.

Model transisi demografi ini merupakan gambaran umum situasi kependudukan dan berbagai yang mempengaruhinya serta dampak yang menyertainya. Bila ditinjau lebih dalam pada tingkat region atau nagara akan muncul gambaran yang menarik, karena dipengaruhi oleh sejarah dan tingkat pembangunan yang sedang dijalaninya. Bila dianalisis piramida penduduk akan bisa memberi penjelasan historis mengenai penduduk dan peristiwa yang tergambar dari kohort piramida penduduk. Piramida penduduk dapat menggambarkan tiga hal, yaitu (1) distribusi umur yang biasanya mengikuti kohort 5 tahunan; (2) rasio penduduk perempuan dan laki-laki; dan (3) rasio ketergantungan pendudun usia dibawah 15 tahun dan diatas 65 tahun terhadap penduduk usia kerja produktif. 


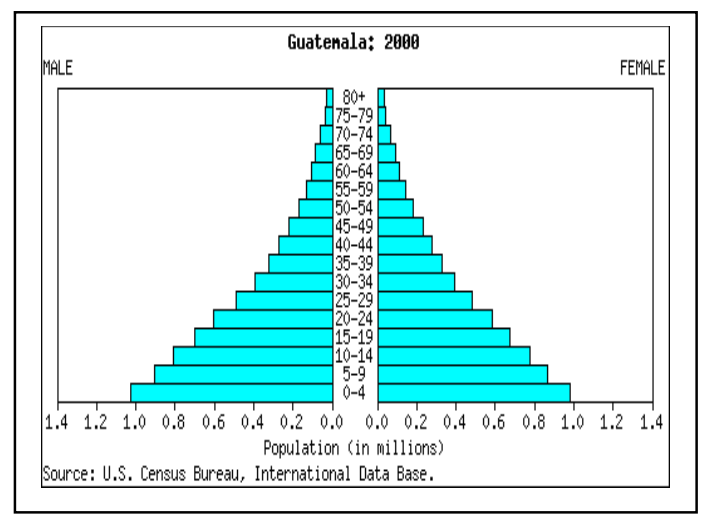

(a)

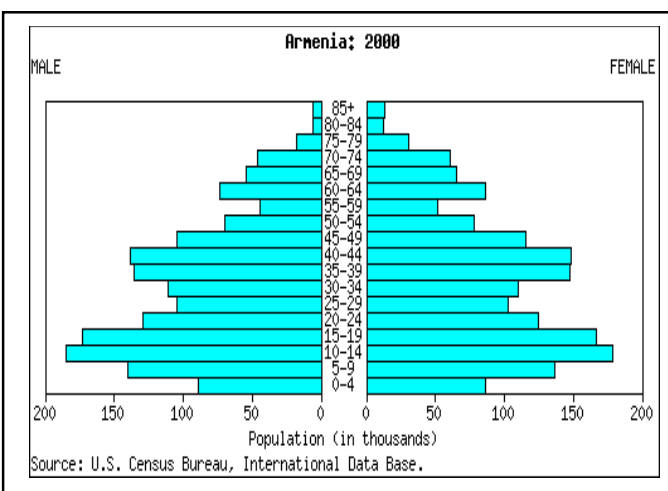

(b)

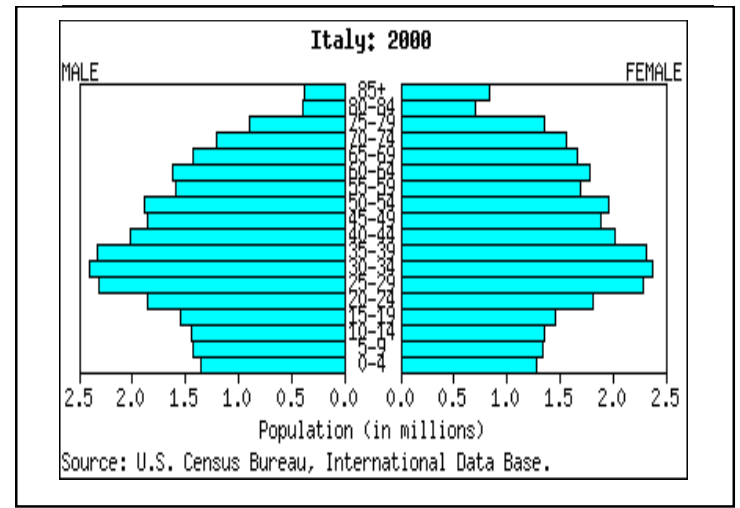

(c)

Gambar 2. Model piramida penduduk tahun 2000 (a) Guatemala (b) Armenia (c) Italia

Model piramida penduduk Guatemala 2000 (Gambar 2a) menunjukkan piramida yang melebar di bagian bawah dan mengerucut diatas secara seimbang kanan dan kiri. Hal ini menandakan bahwa angka kelahiran penduduk Guatemala sangat tinggi dan dalam perkembangan tidak banyak mengalami gejolak. Sebagai negara yang sedang berkembang, model piramida semacam ini umum dijumpai, termasuk juga bentuk piramida penduduk Indonesia.

Model piramida penduduk kedua (Gambar 2b) dapat dilihat pada negara Armenia 2000. Negara ini merupakan pecahan dari Uni Soviet (USSR) yang kini menjadi negara tersendiri. Selama 10 tahun terakhir yaitu antara 1990-2000 terjadi penurunan angka kelahiran yang cukup drastis. Ini bisa kita kaitkan dengan krisis yang terjadi akibat bubarnya Uni Soviet dan berdirinya Armenia sebagai negara tersendiri. Krisis dan masa transisi yang tidak mudah bagi penduduk. Sehingga keadaan ini juga dapat mempengaruhi keinginan untuk mendapatkan anak. Dengan cara melihat bentuk piramida ini kita dapat mengaitkan apa yang terjadi dengan situasi sebuah negeri, kebijakan pemerintah dan respon penduduknya berkaitan dengan kependudukan. 
Bentuk ketiga (Gambar 2c) merupakan piramida penduduk dengan dasar yang ramping di bawah dan gemuk di tengah. Ini dapat diinterpretasi bahwa angka kelahiran terus menyusut dan kelompok usia produktif dominan serta terlihat pula jumlah penduduk usia lanjut $(>65$ tahun) jumlahnya cukup besar. Piramida penduduk Italia tahun 2000 seperti ini merupakan gambaran negara maju yang pada umumnya kaum muda enggan memiliki anak atau hanya mau memiliki anak sedikit. Negara seperti ini juga memiliki tingkat pelayanan kesehatan yang prima, sehingga usia harapan hidup tinggi. Rasio ketergantungan juga relatif rendah karena penduduk usia produktif jumlahnya jauh lebih banyak daripada anak-anak dan manula.

Memperhatikan Model Transisi Demografis dan beragam Piramida Penduduk dapatlah kita pahami mengapa terjadi ledakan penduduk dan rupanya setiap negara memiliki respon kependudukan yang beragam terhadap perkembangan pembangunannya. Ledakan penduduk yang dahsyat itu dapat digambarkan sebagai "Kurva J" yang dalam dua ratus tahun terakhir, sejak revolusi industri mengalami peningkatan pertumbuhan penduduk nyang luar biasa (Kotak 1).

Perkembangan ini amat mencengangkan dan sejak itu masalah-masalah kependudukan dan lingkungan hidup menjadi perhatian. Peradaban umat manusia juga menunjukkan perkembangan yang semakin cepat berubah dan dikhawatirkan menguras sumberdaya dan energi serta menimbulkan polusi dan degradasi lingkungan. Manusia saling berkompetisi mencapai pemenuhan kebutuhan dan bahkan berlomba memenuhi ambisi. Muncul suatu pertanyaan mendasar berkaitan dengan jumlah penduduk dan kemampuan planet bumi menghidupi dan menopang peradaban manusia.

"Orang Perancis menggunakan teka-teki untuk mengajarkan kepada anakanak sekolah, sifat pertumbuhan yang berlipat ganda. Sebuah kolam berisi teratai, semula berisi selembar daun. Tiap hari daun itu berlipat dua: dua lembar pada hari kedua, empat lembar pada hari ketiga, delapan daun pada hari keempat, demikian seterusnya. Pertanyaan teka teki adalah: Bila kolam itu penuh daun teratai pada hari ketigapuluh, kapan kolam itu berisi separohnya? Hari yang kedua puluh sembilan” (Brown, L.R. 1982).

Teka teki tersebut menggambarkan suatu pertumbuhan eksponensial penduduk bumi yang diibaratkan penduduk sebagai daun teratai dan bumi sebagai kolam itu. Kurva J dan teka teki tersebut bisa menggambarkan baik pesimis maupun optimis, berapa jumlah manusia yang dapat ditampung oleh bumi dan pada tingkat konsumsi serta gaya hidup seperti apa sebaiknya kehidupan ini dikelola. Muncul kekhawatiran akan datangnya bencana ekologi 


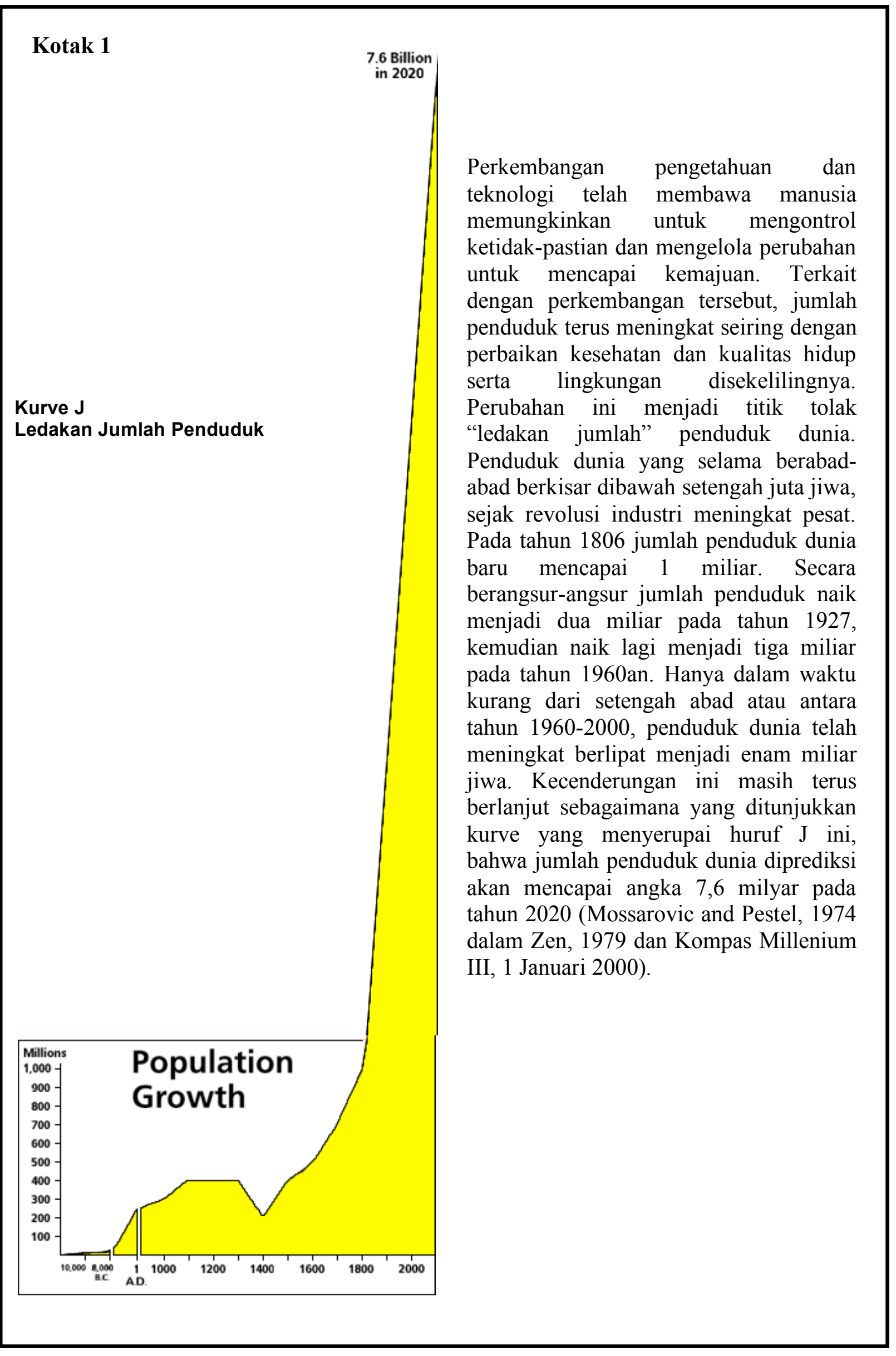


yang dapat menyebabkan daya dukung kehidupan hancur dan sulit dipulihkan lagi. Suatu bencana yang secara sistimetis mengurangi kemampuan hidup generasi mendatang akibat keserakahan segelintir generasi saat ini.

Modernisasi melalui paradigma pertumbuhan, disamping telah menunjukkan manfaatnya bagi sebagian kelompok masyarakat, juga tidak lepas dari kelemahan dan keburukan yang merugikan kelompok masyarakat lainnya. Proyek-proyek modernisasi yang diyakini dapat menyelesaikan sejumlah masalah, ternyata dianggap juga tidak mampu menyelesaikan peradaban manusia. Mahbub ul Haq (1983) menyatakan dalam bukunya Tirai Kemiskinan bahwa:

"Sangat bijak untuk diketahui bahwa pertumbuhan ekonomi adalah suatu proses yang kejam dan keji. Jalan pintas ke sana tidak ada. Inti maknanya ialah mengusahakan supaya pekerja menghasilkan lebih besar dari apa yang dihabiskannya untuk memenuhi kebutuhan pokoknya, serta menanam dan menanam kembali hasil lebih dari yang diperolehnya (Haq. 1983: 13)."

Para aktivis lingkungan terutama yang menganut paradigma Deep Ecology menganggap bahwa modernisasi berarti kerakusan manusia atas alam. Kecenderungan modernisasi yang menggalang akumulasi modal dan pemanfaatan alam sebesar-besarnya, dianggap memiliki dampak mendorong kerakusan manusia atas alam. Gorz, (2002) mengemukakan bahwa pertumbuhan ekonomi yang semestinya dapat menjamin kemakmuran dan kesejahteraan manusia, ternyata lebih banyak memunculkan keinginan-keinginan baru yang tidak pernah terpuaskan, sehingga mengarah pada jalan buntu yang tidak semata-mata bersifat ekonomis, tetapi menimbulkan keterasingan manusia pada alam. Akbar S. Akhmed (1994) mengemukakan lebih jauh bahwa manusia mengalami keterasingan dengan Sang Penciptanya.

"Kita tahu bahwa dunia kita sedang menuju pada kehancuran; jika tetap saja bertindak seperti dulu, laut dan sungai akan menjadi steril, tanah akan menjadi infertile, di perkotaan udara tidak lagi bisa digunakan untuk bernafas lega dan yang bisa bertahan hidup hanyalah specimen-spesimen tertentu yang membentuk ras baru umat manusia, yang diprogram secara genetik untuk bisa bertahan dalam ekologi yang baru. Kita juga tahu bahwa selama seratus lima puluh tahun, masyarakat industri telah berkembang lewat penjarahan secara membabi-buta terhadap cadangan sumberdaya alam, yang penciptaannya memerlukan waktu puluhan juta tahun lamanya; dan bahwa hingga akhir-akhir ini pun, para ekonom baik mereka yang beraliran Klasik maupun Marxist telah menolak pertimbanganpertimbangan jangka panjang dan masa depan, yakni tentang planet ini, biosfer maupun peradaban, dan menganggapnya sebagai suatu hal yang tidak relevan dan reaksioner" (Gorz, A. 2002:17). 
Gidden (2001) juga mengemukakan bahwa peradaban yang dijalani sekarang memperlihatkan bahaya yang justru diciptakan sendiri dan lebih menakutkan dari yang datang dari luar. Beberapa diantaranya dapat menjadi kenyataan suatu bencana besar, seperti resiko ekologis global, bencana nuklir, dan meleburnya perekonomian dunia. Sebagian yang lain mempengaruhi jauh secara langsung pada perilaku individu, seperti diet, pengobatan dan bahkan perkawinan. Pada saat suatu peradaban telah memperlihatkan tanda-tanda keruntuhan, akan muncul suatu pemikiran-pemikiran baru yang mempengaruhi awal lahirnya zaman baru. Nampak telah terlihat tanda-tanda kehidupan saat ini tidak lagi dapat dipertahankan, sehingga akan melahirkan suatu pandangan baru yang membawa suatu perubahan zaman.

"Era kehidupan seperti yang kita jalani sekarang tak pelak lagi akan memunculkan kebangkitan agama dan berbagai filsafat Zaman Baru (New Age), yang berbalik melawan pandangan ilmiah." (Gidden. 2001:31).

Koreksi terhadap pandangan ilmiah, tidak berarti akan menghancurkan semua pandangan dan temuan-temuan yang telah memberikan manfaat pada umat manusia. Koreksi yang dilakukan adalah terhadap suatu pandangan dan pemanfaatan ilmiah untuk tujuan berlebihlebihan yang mengakibatkan ketidak-adilan dan ketidak-seimbangan. Dalam hal ini diperlukan pemaknaan nilai agama guna memberikan inspirasi membangun hubungan manusia, alam dan Sang Pencipta.

\section{Masalah Lingkungan Global}

Krisis lingkungan global tengah terjadi sebagai akibat pembangunan yang terus meningkat. Semenjak Revolusi Industri yang dimulai tahun 1750an telah terjadi banyak perubahan yang memposisikan manusia dengan teknologinya semakin menguasai alam. Manusia mengembangkan teknologi dan berbagai peralatan mesin yang mengkonsumsi energi dan sumberdaya dalam jumlah yang tinggi, sekaligus mengakibatkan kerusakan lingkungan dan polusi yang besar.

Aktivitas pembangunan yang ditopang dengan teknologi maju, telah membawa perilaku manusia menggubah lingkungan hingga melampaui batas-batas daya dukungnya. Modernisasi pembangunan telah membawa perubahan manusia dalam hal kualitas hidup dan gaya hidup konsumtif maupun peningkatan secara kuantitas jumlah penduduk yang memerlukan dukungan sumberdaya dan energi yang tinggi. Pembangunan bagi penduduk yang jumlahnya amat besar tersebut tidak saja secara kuantitatif masih akan terus 
meningkat, juga merubah secara kualitatif pola kebutuhan dan gaya hidup. Teknologi modern dikembangkan dengan skala yang besar dan melampaui daya jangkau kendali manusia.

Seiring dengan kemajuan teknologi dan perubahan pola konsumsi, berbagai persoalan lingkungan mengemuka termasuk pemanasan global dan perubahan iklim. Perubahan lingkungan memang bisa disebabkan faktor alam sendiri, namun selama lima puluh tahun terakhir pengaruh manusia terus meningkat. Pemanasan global saat ini lebih banyak diakibatkan oleh aktivitas manusia yang banyak melepas gas greenhouse ke atmosfir, sebagaimana dikemukakan oleh United Nations Environment Programme:

"A main conclusion of the Intergovernmental Panel on Climate Change (IPCC) Fourth Assessment Report of 2007 was that it is very likely that most of the global warming during the last 50 years is due to the increase in human-made greenhouse gases" (UNEP, 2007:9).

Berbagai penelitian menunjukkan bahwa telah terjadi pemanasan global, yang ditunjukkan dengan meningkatnya suhu atmosfir bumi dan melelehnya salju di puncak-puncak gunung dan kutub bumi. Perubahan itu juga mengakibatkan perubahan iklim yang ditandai dengan berbagai bencana banjir dan kekeringan, panas menyengat di Eropa, badai sering mengamuk di Amerika, banjir semakin sering terjadi di Asia dan kekeringan di Afrika.

Pemanasan global mengakibatkan pencairan es di kutub, sebagaimana dilaporkan bahwa lapisan es yang menutupi Greenland selama satu dekade terakhir abad 20 terjadi kenaikan dua kali lipat dan terus meningkat pada pengamatan tahun 2005. Lapisan es di Greenland dan Antartica merupakan sumber air tawar yang berupa es sebesar 99 persen, sedang 1 persen berupa salju yang menutupi pegunungan tinggi seperti Himalaya, Alpen, Rocky Mountain dan lainnya.

Pemanasan global juga melelehkan salju yang menyelimuti puncak gunung dan mencairkan glacier pegunungan tinggi. Salju tersebut merupakan cadangan air tawar yang penting bagi kehidupan manusia sebagai sumber air bersih, air irigasi maupun sumber energi hydropower terbarukan. Cadangan salju yang menutupi puncak-puncak gunung itu ibaratnya tangki air bersih yang penting bagi kehidupan di bawahnya. Kini tangki air itu terus bocor, cadangan salju terus meleleh dan kontinyuitas ketersediaan air tawar terancam.

Ketika musim panas tiba, salju glacier yang mencair semakin banyak dan tidak pulih lagi di musim dingin berikutnya. Di Montana National Parks misalnya, glacier kini tinggal 27 dari yang tercatat sebelumnya sebanyak 150 glacier pada tahun 1850 (Our Changing 
Planet, FY 2006). Volume es yang mencair lebih banyak dari volume es yang terbentuk, akibatnya dimusim panas dan bertepatan dengan musim hujan semakin besar ancaman banjir terjadi. Sementara di musim kemarau kekurangan air menjadi ancaman bagi kehidupan penduduk yang mengandalkan air bersih untuk kebutuhan sehari-hari dan air irigasi untuk pertanian. Melelehnya salju di beberapa pegunungan mengancam sekitar 2 milyar penduduk yang tergantung pada ketersediaan air bersih dari sistem penampung air alami berupa salju di pegunungan tinggi diatasnya.

Dampak pemanasan global terhadap pulau-pulau kecil dan pesisir juga terasa sebagai ancaman bagi penduduk. UNEP melaporkan adanya kecenderungan kenaikan permukaan air laut dari 1,7 mm per tahun pada abad lalu, kini telah mencapai kenaikan rata-rata per tahun sebesar 3,1 mm per tahun. IPCC dalam laporannya baru-baru ini memprediksi kemungkinan kenaikan air laut sebesar 20 hingga $80 \mathrm{~cm}$ selama abad 21 mendatang (UNEP, 2007).

Kenaikan air laut dan perubahan iklim tentu akan berdampak besar pada kehidupan dan penghidupan penduduk di pesisir dan pulau-pulau kecil. Banjir menjadi ancaman yang nyata bagi kota di pesisir, bahkan tidak ada hujan pun beberapa bagian kota di Semarang dan Jakarta mengalami genangan hingga infrastruktur jalan dan pelabuhan terganggu. Apalagi bila terjadi pasang air laut bersamaan dengan datangnya hujan dengan intensitas tinggi, tak terelakkan lagi terjadi banjir yang menimbulkan masalah kesehatan dan kerugian harta benda.

Dampak perubahan iklim terhadap hujan dan banjir memang dirasakan banyak negara. Kerusakan hutan akibat illegal loging maupun kebakaran hutan dan konversi lahan untuk perkebunan di hulu DAS (Daerah Aliran Sungai) dan meningkatnya intensitas hujan telah menyebabkan sungai-sungai meluap membanjiri permukiman di desa-desa maupun kota di pesisir. Diperkirakan bila pemanasan global terus meningkat dan perubahan iklim terjadi, maka pada akhir abad ini diperkirakan 22 persen lahan basan dan pesisir akan tenggelam. Hal ini amat mengkhawatirkan, mengingat sebagian besar penduduk dunia menempati kota-kota di pesisir yang rawan terhadap kenaikan air laut.

Para ahli meteorologi yang mengamati iklim menemukan fenomena kemarau panjang di sebagian belahan bumi yang disebut El Nino dan munculnya fenomena La Nina hujan dengan intensitas tinggi waktu yang lama sehingga menjadi ancaman banjir. El Nino kemarau panjang yang terjadi pada tahun 1997 telah mengakibatkan kegagalan panen. Di 
Indonesia kemarau panjang tidak saja mengakibatkan krisis ekologis berupa kerusakan lingkungan seperti kematian terumbu karang dan kebakaran hutan; tetapi juga memperparah krisis ekonomi yang sedang terjadi saat itu berlanjut ke krisis sosial politik hingga krisis multidimensi.

\section{Krisis Pembangunan dan Lingkungan di Indonesia}

Indonesia sering disebut negeri kaya sumberdaya alam yang subur makmur, gemah ripah loh jinawi. Sayangnya sebutan itu bagi sebagian besar rakyat Indonesia yang hidup di bawah garis kemiskinan hanyalah fatamorgana. Istilah demikian sering membuat terlena dan kurang bergairah untuk menghadapi tantangan. Kondisi demikian bisa dilihat dari sudut pandang kultur maupun struktur, yang menjadikan bangsa ini tak mampu mengelola sumberdaya alam untuk kemakmuran rakyatnya dan melestarikan lingkungannya untuk kesejahteraan generasi mendatang.

Belakangan, prestasi buruk juga sering dialamatkan pada Indonesia sebagai negara yang sering melakukan pelanggaran hak asasi manusia, pengutang besar, wabah korupsi dan nepotisme, pembajak produk dagang, mafia narkoba, sarang teroris hingga perusak lingkungan. Masalah lain yang masih membelenggu antara lain: kesenjangan antar wilayah, kemiskinan, pengangguran, keresahan dan kerusuhan sosial, kelamahan penegakan hukum, yang kesemuanya secara saling bertautan menjadi simptom atau gejala penyakit yang muncul dalam bentuk krisis.

Potret pembangunan Indonesia tiba-tiba menjadi buram dan kusut diterpa badai krisis moneter yang melanda Asia dan perubahan iklim global termasuk munculnya El Nino pada tahun 1997. Darimana krisis ekonomi bermula? Dawam Raharjo berpendapat bahwa setelah krisis sosialisme yang ditandai dengan ambruknya Uni Soviet awal 1990an, maka krisis Asia diambang akhir 1990an ini adalah krisis kapitalisme. Arif Budiman melihat dari sudut sosiologi bahwa awal krisis ini adalah keserakahan yang terjadi di antara para pelaku pasar uang yang ternyata berdampak pada destruksi perekonomian berbagai negara. Ia berujar "Kapitalisme pada akhirnya memang akan mengalami krisis karena saling menekan". Sedangkan Roekmono Markam berpendapat bahwa ada tuntutan baru dalam tata ekonomi internasional. Lebih lanjut ia menjelaskan "Harus diakui bahwa adanya opening economic atau globalisasi dan adanya gejala spekulasi global, adanya hot money dimana uang singgah sebentar di Indonesia untuk cari keuntungan lalu lari ke tempat lain dengan meninggalkan utang" (Adil 24-30 Desember 1997). Krisis yang dialami Indonesia 
dapat dilihat dari berbagai pandangan mulai perubahan pola perilaku individu dan masyarakat, maupun dinamika perubahan yang memiliki kaitan global.

Tidak hanya krisis ekonomi, berbagai masalah lingkungan seperti banjir dan kekeringan silih berganti terjadi diberbagai daerah. Indonesia yang dikenal memiliki sumberdaya hutan mengalami kerusakan yang sangat parah akibat kebijakan eksploitasi yang dilakukan melalui ijin HPH yang diberikan pada para kroni kekuasaan. Laju kerusakan hutan terus meningkat dengan dampak lingkungan dan kemiskinan penduduk lokal yang semakin parah.

Semula luas hutan yang masih baik, menurut sumber dari tahun 1941, adalah 120 juta ha. Pada saat ini angka itu mestinya sudah tidak sesuai lagi. Konversi lahan hutan untuk berbagai kegiatan pembangunan tentu telah banyak mengurangi luas hutan di Indonesia. Kerusakan hutan di Indonesia telah mencapai suatu taraf yang mengkhawatirkan. Menurut catatan pemerintah laju kerusakan hutan mencapai 1,6 hingga 2 juta hektar per tahun. Forest Watch Indonesia menilai bahwa laju kerusakan tersebut membuat Indonesia tergolong negara yang mengalami kerusakan lingkungan tercepat di dunia. Luas hutan Indonesia selama lima puluh tahun terakhir diperkirakan terus menyusut, dari 162 juta hektar menjadi 98 juta hektar.

Walhi mencatat 96,5 juta hektar atau 72 persen dari 134 juta hektar hutan tropis Indonesia telah hilang, sehingga hutan tersebut tinggal 37,5 juta hektar. Kerugian yang diderita akibat kerusakan yang mencapai 1,6 juta hektar per tahun, menurut Menteri Kehutanan yang waktu itu dijabat Muhammad Prakoso, Indonesia mengalami kerugian yang sangat fantastis sebesar Rp 30,42 triliun per tahun (Tempo 3 April 2002). Laju perusakan hutan di Indonesia mempunyai angka berbeda-beda, tergantung darimana sumber data dan bagaimana analisisnya.

Terdapat beberapa faktor yang menyebabkan perusakan hutan di Indonesia, namun umumnya faktor-faktor tersebut berkaitan erat dengan praktek-praktek pembangunan dan sistem produksi yang tidak berkelanjutan. Kerusakan hutan pada umumnya diakibatkan oleh penebangan besar-besaran dan pembukaan lahan untuk perkebunan, transmigrasi maupun pertambangan. Begitu dahsyat dampak akibat kebakaran hutan 1997 dan 1998, sehingga perlu dicatat dalam sejarah tragedi lingkungan dan kemanusiaan akhir abad 20 di Indonesia. Kebakaran hutan, tidak hanya berdampak pada kesehatan pernapasan, kegagalan panen, kekeringan, kerugian berbagai sektor bisnis terutama penerbangan udara; 
namun juga banyak dampak yang tersembunyi yang muncul dalam jangka panjang. Banjir merupakan dampak ikutan yang terjadi hampir setiap musim penghujan. Dampak yang paling parah adalah dalam jangka panjang banyak keragaman hayati yang rusak dan punah.

Disisi lain, lingkungan perairan laut Indonesia juga mengalami eksploitasi dan pencurian sumberdaya perikanan yang terus meningkat. Lautan Indonesia dikenal sebagai wilayah Mega Marine Biodiversity terbesar di dunia, memiliki 8.500 spesies ikan, 555 spesies rumput laut dan 950 spesies terumbu karang. Potensi kelautan Indonesia yang besar tidak hanya menjadi tempat hidup ikan bagi sektor perikanan, tetapi menyimpan sumberdaya mineral untuk industri, dan memiliki keindahan untuk pengembangan pariwisata. Tiga kegiatan ekonomi ini saja sebagai contoh, potensial untuk menyerap puluhan juta tenaga kerja, menghasilkan devisa, menumbuhkan mata rantai kegiatan hulu dan hilir yang besar.

Tantangan yang dihadapi adalah berbagai masalah pencurian ikan oleh kapal-kapal asing, kerusakan habitat laut akibat pemboman dan peracunan, dukungan permodalan dan teknologi, pengorganisasian nelayan Indonesia dan pemasaran produk perikanan, serta berbagai masalah yang terkait dengan penegakan hukum dan aturan main di bidang kelautan. Dewan Maritim Indonesia memberikan gambaran bahwa kelemahan pembangunan kelautan masih sangat banyak. Dikemukakan bahwa industri pelayaran Indonesia dewasa ini masih sangat memprihatinkan, 97\% kegiatan ekspor dan impor, 94\% pelayaran domestik masih dilayani oleh kapal-kapal berbendera asing, sementara industri pelayaran tradisional semakin terdesak.

Kekayaan alam dan budaya wilayah kepulauan Indonesia tidak banyak artinya apabila sumberdaya manusia masih terbatas dalam melakukan inovasi produksi dan promosi pasar. Oleh karena itu dalam mengatasi krisis yang perlu dibenahi adalah manusianya, melalui kesehatan, pendidikan, cara berfikir dan kesadaran baru, etos kerja serta upaya mewujudkan perubahan dalam berbagai bidang kehidupan. Kebijakan pembangunan perlu disusun dengan pemahaman pluralitas budaya maupun pertimbangan atas keragaman sumberdaya wilayah baik yang bersifat hayati maupun fisik.

Dari permasalahan kehutanan dan kelautan saja sudah banyak sekali yang harus dibenahi, apalagi bila kita menyelami permasalahan pembangunan dan lingkungan hidup secara lebih detail akan lebih banyak lagi yang harus dihadapi dan diselesaikan. Oleh karena itu perlu kiranya untuk mencari jalan kembali pada yang benar dan menemukan jati diri manusia sebagai pemimpin. 


\section{Menemukan Jati Diri Manusia}

Kita harus mencari jalan kembali yang benar, yaitu pentingnya petunjuk arah dari ajaran wahyu untuk mengatasi berbagai persoalan peradaban manusia. Mahbub Ul Haq memberikan pandangan bahwa pembangunan haruslah bertujuan untuk membasmi bentukbentuk terburuk kemiskinan. Sasaran pembangunan haruslah ditetapkan atas dasar upaya mengurangi dan akhirnya melenyapkan kurang gizi, penyakit, buta huruf, hidup melarat, pengangguran dan kesenjangan. Kritik yang dilancarkan Mahbub Ul Haq mulai diterima di kalangan Negara-negara kaya dan maju serta tentu saja di dukung oleh negara-negara miskin dan berkembang.

Kini upaya tersebut terus diusahakan melalui berbagai upaya seperti Pembangunan Berkelanjutan, Agenda 21 dan Millenium Development Goals, sebuah komitmen bersama untuk mencapai perbaikan pembangunan dan lingkungan hidup. Dalam dokumen-dokumen tersebut disebutkan pentingnya memberantas kemiskinan dan pemiskinan. Jeffrey Sachs (2005) menuliskan bukunya The End of Poverty yang merupakan ajakan untuk menuntaskan masalah kemiskinan yang ekstrim, melalui salah satunya juga mempromosikan Pembangunan Berkelanjutan.

Pembangunan Berkelanjutan yang dirumuskan dalam laporan Our Common Future atau dikenal dengan Brundtland Report, sebagai pembangunan yang memenuhi kebutuhan masa kini tanpa mengorbankan hak pemenuhan kebutuhan generasi mendatang.

"Sustainable development is the development that meets the needs of the present without compromising the ability of future generations to meet their own needs" (WCED, 1987:8).

Konsep tersebut memiliki makna yang luas dan menjadi payung bagi banyak variasi konsep, kebijakan dan program pembangunan yang amat beragam. Pembangunan berkelanjutan merupakan paradigma baru pembangunan yang memiliki interpretasi dan konsep yang beragam. Konsep yang diajukan negara maju belum tentu tepat untuk dilaksanakan di negara berkembang, demikian pula konsep yang diajukan oleh negara sedang berkembang belum tentu dapat diterima oleh negara maju. Hingga sekarang ada ratusan konsep dan definisi pembangunan berkelanjutan. Hal ini menunjukkan bahwa isu ini telah berkembang cepat dan dapat tumbuh secara beragam dalam implementasinya.

Pembangunan Berkelanjutan yang diperbincangkan oleh banyak kalangan, setidaknya membahas empat hal: pertama, upaya memenuhi kebutuhan manusia yang ditopang dengan kemampuan daya dukung ekosistem; kedua, upaya peningkatan mutu kehidupan 
manusia dengan cara melindungi dan memberlanjutkan; ketiga, upaya meningkatkan sumberdaya manusia dan alam yang akan dibutuhkan pada masa yang akan datang; keempat, upaya mempertemukan kebutuhan-kebutuhan manusia secara antar generasi (Baiquni, M dan Susilawardani, 2002).

Upaya-upaya yang dilakukan guna mewujudkan keseimbangan pembangunan dan lingkungan, tentunya sangat tergantung bagaimana kualitas manusia. Manusia harus memahami jatidiri dan eksistensi bahwa setiap manusia memiliki mandat sebagai pemimpin di bumi atau dalam bahasa Al Qur'an sebagai Khalifatullah fil Ardh. Islam mengajarkan bahwa alam adalah ciptaan dan anugerah Allah SWT yang diberikan pada manusia untuk dikelola dan dimanfaatkan secara baik, bijak dan hikmah.

Alam semesta memiliki keseimbangan dan keharmonisan sehingga masing-masing berfungsi sebagaimana mestinya yang di atur dengan hukum-hukum yang tunduk pada kehendak Sang Khaliq. Kedudukan manusia sebagai makhluk yang dibekali akal fikiran, indera dan perasaan adalah makhluk yang diberi amanat oleh Sang Khaliq sebagai pemimpin di muka bumi. Kedudukan manusia diantara makhluk lainnya memiliki keistimewaan dibanding makhluk yang lainnya. Manusia diberi tanggungjawab memikul kewajiban untuk berbuat baik di bumi dengan dibekali pedoman kitab suci dan keteladanan para nabi.

"Ingatlah ketika Tuhan berfirman kepada para malaikat: 'Sesungguhnya Aku hendak menjadikan seorang khalifah di muka bumi'. Mereka berkata: 'Mengapa Engkau hendak menjadikan (khalifah) di bumi itu, orang yang akan membuat kerusakan padanya dan menumpahkan darah, padahal kami sementara bertasbih dengan memuji Engkau dan mensucikan Engkau?'. Tuhan berfirman: 'Sesungguhnya Aku mengetahui apa yang tidak kamu ketahui' (Qur'an, Al Baqoroh:30).

Manusia diberi kemerdekaan yang dianugerahi dengan akal dan budi untuk menjadi pemimpin di muka bumi. Keberadaan manusia di muka bumi yang berkeyakinan dan berpedoman Al Qur'an akan menjadikan manusia tersebut memiliki manfaat bagi alam, yang sering diistilahkan dengan Rahmatan lil alamin. Manusia memang diberi anugerah untuk memanfaatkan alam sebagai wahana untuk berkembang biak dan mencapai kemakmuran. Manusia diberi amanat untuk mengelola alam. Segenap tindakan manusia akan dimintai pertanggungjawaban apa yang telah dilakukan selama hidup di dunia.

Manusia selalu diingatkan melalui ritual ibadahnya dan melalui hubungan antar manusia yang dituntunkan melalui Amar makruf, nahi nungkar yaitu menyerukan kebaikan dan 
mencegah kejahatan. Manusia seringkali lalai dan lupa akan kedudukan sebagai pemimpin. Setiap manusia diminta untuk menebarkan kebaikan agar kehidupan menjadi lebih baik. Menebarkan kebenaran kemudian ditumbuhkan agar dapat manfaat dari bibit-bibit yang tumbuh menjadi kebaikan. Manusia diminta pula untuk mencegah kemungkaran, karena keburukan itu akan membawa bencana bagi manusia dan alam semesta.

Tantangan yang paling berat sebagai pemimpin, justru mengendalikan dirinya sendiri. Setiap kenaikan derajat dan kualitas kepemimpinan sungguh penuh dengan ujian dan cobaan. Manusia selalu akan diuji apakah ia layak meningkat kualitas dan derajatnya atau turun merosot karena tidak dapat menerima amanat kepemimpinan yang lebih tinggi. Manusia juga diberi cobaan, apakah cobaan itu berupa kenikmatan yang melimpah ataukah kesulitan yang membebani.

Seringkali seorang pemimpin ketika diuji dengan kesulitan, dapat lulus dan memperoleh derajat yang lebih tinggi. Tetapi banyak juga diantara pemimpin yang tidak lulus ujian justru ketika diuji dengan kenikmatan yang melimpah dan serba kemudahan. Manusia menjadi lupa dan terjerumus menjadi sombong dan lupa diri ketika semuanya dapat diperoleh dengan mudah. Kemungkaran terhadap nikmat akan menjadi bencana, maka seringkali manusia harus berdo’a, agar mampu mensyukuri kenikmatan.

"Ya Tuhanku, tunjukilah aku untuk mensyukuri ni'mat Engkau yang telah Engkau berikan kepadaku dan kepada ibu bapakku dan supaya aku dapat berbuat amal yang saleh yang Engkau ridlhai; berilah kebaikan kepadaku dengan (memberi kebaikan) kepada anak cucuku. Sesungguhnya aku bertaubat kepada Engkau dan sesungguhnya aku termasuk orang-orang yang berserah diri". (Qur'an, Al Ahqaaf: 15).

Do'a ini sesungguhnya merupakan pengharapan yang tidak hanya memikirkan diri sendiri, tetapi makna yang terkandung juga adalah do'a untuk kebaikan anak cucu. Jadi gagasan Pembangunan Berkelanjutan yang membahas keadilan dan kebaikan antar generasi ke depan, bukan konsep baru. Agama telah lebih dahulu mengupas dan menjelaskan, menganjurkan serta memerintahkan untuk tidak melakukan kerusakan di muka bumi.

Manusia diingatkan bahwa kerusakan di muka bumi, baik di laut maupun di darat, merupakan akibat tindakan ulah tangan manusia. Kerusakan di muka bumi tersebut dapat ditafsirkan berupa kerusakan moral manusia dan kerusakan fisik sebagai akibat kerakusan dan keserakahan manusia. Jadi memang tidak dapat dipisahkan rentetan kerusakan mulai kerusakan moral hingga kerusakan lingkungan. Bila kita bersedia belajar dari sejarah, ada tiga aktor utama yang seringkali membuat kerusakan dimuka bumi dari masa ke masa, 
yaitu (1) pengasa yang dzalim yang disimbolkan oleh Fir'aun; (2) orang kaya yang tamak atau rakus yang digambarkan oleh sosok Qorun dan (3) ulama dan ilmuwan pengkhianat, suka memutar balikkan kebenaran yang dicontohkan oleh sosok Hamam. Bila mereka ini bekerjasama, maka rusaklah negeri itu.

"Dan bila dikatakan kepada mereka 'Janganlah kamu membuat kerusakan di muka bumi', mereka menjawab, 'sesungguhnya kami orang-orang yang mengadakan pembangunan'. Ingatlah, sesungguhnya mereka itulah orangorang yang membuat kerusakan, tetapi mereka tidak sadar (Qur'an, Al Baqoroh:11-12)".

Berbagai upaya pembangunan, sesungguhnya justru melakukan kerusakan. Mengapa demikian? Karena banyak prinsip ahlak dan budi pekerti dilanggar demi melanggengkan kekuasaan serta mengumbar hawa nafsu keserakahan.

Manusia yang dinobatkan sebagai khalifah di muka bumi dianugerahi kehidupan, kemerdekaan dan hidayah. Manusia yang dibari amanat yang begitu berat yaitu menjadi pemimpin di muka bumi. Manusia di bekali dengan daya hidup berupa indera dan nafsu; namun hal itu juga diberikan pada mahluk hidup semacam binatang. Manusia kemudian dibekali kemerdekaan yaitu kemerdekaan akal fikiran dan rasa yang diasah dengan dzikir, itupun tidaklah cukup. Hanya manusia yang mendapat hidayah lah yang dapat menjadi pemimpin yang baik, yaitu hidayah ilmu dan iman. Oleh karena itu betapa tinggi derajat orang orang berilmu sekaligus beriman (Abdurrahim, I. 1995).

Mencermati peradaban manusia dan kecenderungan perubahan yang terjadi, akan sangat mengkhawatirkan bila milyaran manusia penghuni bumi ini tidak memiliki sifat kepemimpinan. Masa depan umat manusia tidak dapat dititipkan atau diwakilkan pada beberapa gelintir pemimpin elit yang ada, namun harus disadarkan bahwa setiap manusia diturunkan ke bumi sebagai pemimpin. Setiap manusia telah dimandati menjadi pemimpin dan kelak akan dimintai pertanggungjawaban apa yang telah diperbuat dengan kepemimpinannya itu.

Kesadaran setiap manusia adalah pemimpin dan keteladanan menjadi cermin pribadinya, merupakan harapan bagi kelangsungan hidup manusia yang lebih baik. Ditengah berbagai tantangan kehidupan, agama menjadi kompas penunjuk arah menuju jalan yang benar. Kepemimpinan sebagai kunci Pembangunan Berkelanjutan, yaitu manusia yang dengan teguh memeluk agamanya, akan mendapat hidayah dan mampu mengemban amanat sebagai pemimpin di muka bumi. Setiap manusia adalah pemimpin, yang akan dimintai pertanggungjawaban atas kepemimpinannya, itulah Khalifatullah fil Ardh 


\section{Referensi}

1. Abdurrahim, I. 1995. Bahan ceramah Hikmah Fajar. di RCTI 10 November 2005. Jakarta

2. Ahmed, Akbar S. 1992. Postmodernisme: Bahaya dan harapan Bagi Islam. Mizan, Bandung.

3. Baiquni, M. dan Susilawardani. 2002. Pembangunan Yang Tidak Berkelanjutan: Refleksi Kritis Pembangunan Indonesia. ideAs dan TransMedia Global Wacana.

4. Brown, L.R. 1981. Hari Yang Keapuluh Sembilan. Diterjemahkan dalam Bahasa Indonesia oleh Yayasan Obor.

5. Dwidjoseputro, D. 1991. Ekologi Manusia dengan Lingkungannya. Penerbit Erlangga. Jakarta.

6. Giddens, Anthony. 2001. Runaway World: Bagaimana Globalisasi Merombak Kehidupan Kita. Gramedia. Jakarta

7. Gorz, Andree. 2002. Ekologi dan Krisis Kapitalisme. Insist Press. Yogyakarta

8. Haq, Mahbub ul. 1983. Tirai Kemiskinan: Tantangan-Tantangan untuk Dunia Ketiga. Yayasan Obor Indonesia. Jakarta.

9. Kompas. 2000. "Tonggak Sejarah Ilmu Pengetahuan, Sosial, dan Politik Yang Menentukan Hidup Kita Saat Ini”. Dalam Harian Kompas: Menuju Millenium III, 1 Januari 2000. Kompas, Jakarta.

10. Mubyarto. 1987. Ekonomi Pancasila. Gagasan dan Kemungkinan. LP3ES. Jakarta.

11. Rahardjo, M. Dawam. 1984. Tranfsormasi Pertanian, Industrialisasi dan Kesempatan Kerja. Penerbit Universitas Indonesia. Jakarta.

12. Sachs, Jeffrey. 2005. The End of Poverty: How We Can Make It Happen in Our Lifetime. Pinguin Books. London

13. UNEP. 2007. Global Outlook of Ice and Snow. United Nations Environment Program. Nairobi. Kenya.

14. UNFPA 1991, Population, Resources and the Environment: The Critical Challenges, United Nations Population Fund. New York.

15. Walhi. 1999. Gugatan Perbuatan Melawan Hukum yang Dilakukan Penguasa. Gugatan ke Presiden RI dan 9 Menteri . Jakarta. August 16.

16. WCED 1987. Our Common Future. World Commision on Environment and Development.

17. Zen, M.T. 1979. Menuju Kelestarian Lingkungan Hidup. Yayasan Obor Indonesia. Jakarta.

\section{Media massa}

1. Adil Mingguan no 13, 24-30 Desember 1997

2. Tempo Koran Harian, 3 April 2002 